\title{
आमाको गीत : २ कवितामा बिम्बविधान
}

\author{
राजेश विद्रोही \\ उपप्राध्यापक \\ नेपाली विभाग, महेन्द्र बहुमुखी क्याम्पस, धरान, त्रिभुवन विश्वविद्यालय, नेपाल \\ rajeshbidrohi@gmail.com
}

DOI: https://doi.org/10.3126/dristikon.v11i1.39168

\section{लेखसार}

यो अध्ययन कवि हेमन यात्रीको पहाड मसितै यात्रा गई्छ कविता सड्ग्रहमा सड्कलित आमाको गीत : २ कवितामा प्रयुक्त बिम्बहरूको विश्लेषणमा केन्द्रित छ। कवि हेमन आफ्ना कविताहरूमा विभिन्न विषय क्षेत्रका बिम्बहरू प्रयोग गर्न रुचाउँछन्। उनी बिम्बात्मक अभिव्यक्तिमार्फत् आफ्ना कवितालाई सुन्दर र काव्यिक बनाउँछन्। पहाड मसितै यात्रा गई्छ कविता सड्ग्रहमा सड्कलित आमाको गीत : २ कवितामा पनि उनले विभिन्न प्रकारका बिम्बहरूको प्रयोग गरेका छन्। ती बिम्बहरू जीवन र जगत्का विविध विषय क्षेत्रहरूसँग सम्बन्धित छन् । समीक्ष्य कवितामा कस्तो बिम्ब-योजना छ र यसमा के कस्ता बिम्बहरूको प्रयोग गरिएको छ भन्ने विषयलाई यस अध्ययनमा विश्लेषण गरिएको छ। विम्बहरूको प्रयोगले कविताको भावलाई कसरी प्रभावकारी र बोधगम्य बनाएको छ भन्ने विश्लेषण पनि यहाँ गरिएको छ। यो बिम्बप्रधान कविता हो र कवि हेमनले प्रस्तुत कवितामा युद्धमा छोरा गुमाएकी आमाको कारुणिक अवस्थालाई बिम्बबहुल अभिव्यक्तिका माध्यमबाट सुन्दर ढड्गले चित्रण गरेका छन् । नेपाली ग्रामीण पहाडी जीवनको सग्लो चित्र कोर्ने क्रमा कविले यस कवितामा पहाडी प्रकृति र दिनचर्यालाई बिम्बात्मक रूप दिएका छन् । विम्बहरूको सुन्दर र आकर्षक प्रयुक्तिले कवितालाई हृदयसंवेद्य र बोधगम्य बनाएको छ। सामग्री सङ्कलनका क्रममा पहाड मसितै यात्रा गई्छ कविता सड्ग्रहमा सड्कलित आमाको गीत : २ कवितालाई प्राथमिक स्रोतका रूपमा तथा कविता र बिम्बहरूबारे लेखिएका समीक्षा-समालोचनालाई द्वितीय स्रोतका रूपमा लिएर व्याख्यात्मक, वर्णनात्मक र विश्लेषणात्मक विधिबाट निष्कर्षमा पुगिएको छ।

शब्दकुज्जी : बिम्ब, संस्कृति, प्रतीक, सादृश्य, उपमाउपमेय, चिद्वैषम्य

\section{विषयपरिचय}

हेमन यात्री नेपाली कविताको क्षेत्रमा परिचित नाम हो । विभिन्न पत्रपत्रिकामा प्रकाशित फुटकर कविताहरू तथा एकमात्र कवितासड्ग्रह पहाड मसितै यात्रा गछ (२०६९) बाट नै उनी आफ्नो परिचय बनाउन सफल भएका छन्। पहिलो कवितासड्ग्रहबाट नै मौलिक शैली र कवितामा निजी अनुहार निर्माण गर्न सफल कवि हेमनले नेपाली कवितामा आफ़नो टड्कारो उपस्थिति जनाइसकेका छन्।

नेपाली कवितामा फराकिलो र उज्यालो बाटो निर्माण गर्दे गरेका उनी हृदयका कवि हुन् । उनका कविताहरूले हृदयको किनारालाई छुन्छन्। हार्दिक भईकन पनि मस्तिष्कलाई समेत स्पर्श गर्न सक्नु उनका कविताको थप वैशिष्ट्य हो। कोमल र लालित्यपूर्ण भाषामा आफ्ना भाव अभिव्यक्त गर्न सिपालु हेमन आफ्नो माटो, जाति, भाषा र संस्कृतिलाई अगाध माया गई् । मानवतावादी कवि हेमनले आफ्ना कवितामा मानवीय संवेदनाका विविध भावहरूलाई बिम्बमा उनेर आकर्षक बनाएका छन्। उनले नवीन बिम्बहरूको प्रयोगमार्फत् 
कवितालाई काव्य-संसारको नूतन क्षितिजमा पुय्याएका छन् । यो उनको मात्र होइन, नेपाली कविताकै उपलब्धि हो । उनले आफ्ना कवितामा प्रणयका विविध भावहरूका साथै समकालीन जीवनका अनेक विसड्गति र दु:खी जनका उच्छूवासहरूलाई स्थान दिएका छन् ।

उनको कवितासड्ग्रह पहाड मसितै यात्रा गई्छमा यस्तै विविध भाव र भङ्गिमाका कविताहरू सङ्कलित छन् । विशेषतः उनी समाज र राज्यबाट किनारीकृत समुदायका पीडा र व्यथालाई वाणी दिने सांस्कृतिक कवि हुन् । हेमन शोषित-उत्पीडित समुदायका पीडा र तिनका बाध्यताहरूलाई प्रस्तुत गर्ने स्रस्टा हुन् । उनका अधिकांश कवितामा विपन्न तथा दमित-उत्पीडित समुदायका आवाज मुखरित भएका छन् । राज्यबाट वर्षोंदेखि दमित र अपहेलित समुदायको आत्मसम्मान, पहिचान र गौरवलाई उच्च बनाउन उनले तिनको जीवनका कष्ट, वेदना र घाउहरूलाई आफ्ना कवितामा काव्यिक अभिव्यक्ति दिएका छन् । उनका कवितामा पूर्वी पहाडमा बसोवास गर्ने किराती संस्कृति र जीवनशैली जीवन्त बनेका छन्। किराती सांस्कृतिक बिम्ब, प्रतीक र मिथकहरूको प्रयोग उनका कविताहरूको अर्को आकर्षक पाटो हो। मातृभाषाका कतिपय शब्दहरूको प्रयोगबाट उनले आफ्ना कवितालाई ओजिलो बनाएका छन् । यिनै सुन्दर प्रयोगहरूमार्फत् कवि हेमनले आफ्ना कवितालाई टाढैबाट चिन्न सकिने निख्वर रङ पनि दिएका छन् । यसलाई नेपाली कविताकै उपलब्धि मान्नुपई।

समीक्ष्य कवितासड्ग्रह पहाड मसितै यात्रा गर्छमा पनि कवि हेमनका यस्तै सुन्दर विम्बबहुल कविताहरू छन्। ११६ पृष्ठमा फैलिएको यस कृतिमा ३६ वटा कविताहरू छन्। 'आमाको गीत : २' यस सड्ग्रहको दोस्रो कविता हो। यसमा युद्धमा बेपत्ता छोराको सम्कनामा व्यथित आमाको पीडादायी अवस्थालाई जीवन्त रूपमा प्रस्तुत गरिएको छ। यो नै विश्लेष्य कविता हो । प्रस्तुत कवितामा विविध विम्बहरूको आकर्षक संयोजनबाट भावलाई हार्दिक र प्रभावकारी बनाइएको छ। यी विम्बहरूले नेपालको ग्राम्य र प्राकृतिक परिवेशको सजीव चित्र प्रस्तुत गरेका छन्। छोरा गुमाएकी आमाको भ्रान्त मनोदशा तथा युद्धले दिने पीडादायी परिणामलाई सजीव रूपमा प्रस्तुत गर्न कवितामा विम्बहरूको प्रशस्त प्रयोग गरिएको छ। यहाँ तिनै विम्बहरूको विश्लेषण गरिएको छ। यी विम्बहरूले कवितालाई सम्प्रेष्य बनाएका छन्।

नेपालमा सन्चालन भएको दशक (२०४२-२०६२) लामो सशस्त्र माओवादी दून्दूका क्रममा थुप्रै आमाबाबुहरूले बुढेसकालको सहारा मानिने छोरा गुमाए भने हजारौं बालबालिकाले आफ्ना संरक्षक अभिभावक गुमाए। त्यस दून्दूका अनेक त्रासद कथाका घाउहरू नेपाली सामाजिक जीवनमा अहिले पनि यत्रतत्र छन्। प्रस्तुत कविताले तिनैमध्ये एउटा दु:खान्त कथाको घाउलाई सङ्केत गरेको आभास हुन्छ। हुन त कुनै पनि युद्धको परिणाम सकारात्मक हुँदैन । यो विषय जान्दा जान्दै पनि मानव समाज युद्ध विभीषिका भोग्न अभिशप्त छ। पृथ्वीको कुनै न कुनै भागमा कुनै न कुनै कारणले युद्ध भइरहेकै हुन्छ। युद्धले छाड्ने त्रासद छाप बिलाउन दशकौँ लाग्न सक्छ। यसका लागि सबैको सकारात्मक प्रयास अपेक्षित हुन्छ।

युद्धले छाडेका यस्ता अनेक घाउहरू नेपाली जीवनका पत्र-पत्रमा छोपिएर बसेका छन्। ती घाउलाई कोट्याएर पीडालाई बल्काउनु बुद्धिमानी हुँदैन तर सुन्दर भविष्यका लागि अतीतलाई सम्भिनु पनि उत्तिकै आवश्यक छ। भनिन्छ - अतीतलाई बिर्सने व्यक्ति वा समुदायले सुन्दर भविष्यको गोरेटो खन्न सक्दैन। कविले सुन्दर र उज्ज्वल भविष्यकै लागि अतीतको पीडादायी घटनालाई सम्काउन खोजेका छन् । त्यसले छाडेका वेदना देखाएर पाठकलाई भविष्यप्रति सचेत हुनका लागि परोक्ष रूपमा सन्देश दिन खोजेका छन्। समुन्नत र शान्त भविष्यका लागि अतीतबाट पाठ सिक्नु आवश्यक हुन्छ। युद्धग्रस्त अतीतलाई सम्काउन प्रस्तुत कवितामा कविले बुढेसकालको सहारा गुमाएकी आमाको कारुणिक अवस्थाको चित्रण मर्मस्पर्शी ढङ्गले गरेका छन् । 


\section{समस्याकथन}

कवि हेमनको पहाड मसितै यात्रा गई्छ कवितासड्ग्रहका सम्बन्धमा धेरै समालोचक, चिन्तक र शोधार्थीहरूले कलम चलाइसकेका भए पनि यसभित्र सङ्कलित आमाको गीत : २ कवितामा प्रयुक्त बिम्बहरूबारे छुट्टै अध्ययन गरिएको पाइँदैन । प्रस्तुत कवितामा कस्ता बिम्बहरूलाई कसरी उनिएको छ भन्ने विषयलाई यहाँ मूल समस्याका रूपमा लिइएको छ। यो मूल समस्याका साथै यससँग जोडिन आउने अन्य समस्याहरूलाई बुँदागत रूपमा यस प्रकार प्रस्तुत गर्न सकिन्छ :

(क) कवितामा बिम्बको कस्तो महत्त्व हुन्छ ?

(ख) आमाको गीत : २ मा के कस्ता बिम्बहरूको प्रयोग गरिएको छ ?

\section{शोधको उद्देश्य}

समस्या कथनमा उठाइएका प्रश्नहरूको समाधान खोज्नु नै प्रस्तुत अध्ययनको मूल उद्देश्य हो, जसलाई निम्नलिखित बुँदामा प्रस्तुत गरिएको छ :

(क) कवितामा बिम्बको महत्त्व खोज्नु र

(ख) आमाको गीत : २ कवितामा प्रयुक्त बिम्बहरूको विश्लेषण गर्नु ।

\section{सीमाङ्कन}

प्रस्तुत अध्ययन कवि हेमन यात्रीको कविता आमाको गीत : २ मा प्रयुक्त बिम्बहरूको विश्लेषणमा केन्द्रित छ। उनकै कवितासड्ग्रह पहाड मसितै यात्रा गर्छका अन्य कविताहरूको अध्ययन यहाँ गरिएको छैन। आमाको गीत : २ कै पनि अन्य कोणबाट अध्ययन गरिएको छैन, त्यसमा प्रयुक्त बिम्बहरूलाई मात्र केलाइएको छ। यो नै यस अध्ययनको सीमा हो ।

\section{पूर्वकार्यको समीक्षा}

कविता साहित्यको शक्तिशाली विधा हो। कवितालाई भाषाको सबैभन्दा सुन्दर र आकर्षक रूप मानिन्छ। त्यसैले कविता धेरै लेखिने विधाहरूमा पछ। कविताका बारेमा समीक्षा र समालोचना पनि प्रशस्त गर्ने गरिन्छ। कवि हेमन यात्रीका कविताहरूबारे पनि विभिन्न अध्येताहरूले समालोचना गरेका छन्। नेपाली अध्येताहरूले कवि यात्रीका कविताका विविध पक्षमा अध्ययन-अनुसन्धान गरेका छन् । उनका कविताहरूबारे समीक्षात्मक टिप्पणीहरू प्रशस्त लेखिएका छन्। समालोचकहरूले उनका कविताहरूको विश्लेषण विभिन्न कोणबाट गरेका छन्। धेरै समालोचकहरूले अहिले पनि उनका कविताबारे नवीन दृष्टिकोणबाट विहड्गम समीक्षण र विश्लेषण गरिरहेका छन् । उनका सिर्जनाका विविध आयाम र प्रवृत्तिमा केन्द्रित भएर समालोचक तथा शोधार्थीहरूले चर्चा-परिचर्चा गरिरहेका छन् । अभि सुवेदी, अविनाश श्रेष्ठ, दिनेश अधिकारी, महेश पौड्याल, कुमारी लामालगायतले उनका कविताका विविध पाटोलाई केलाउँदै विश्लेषण गरेका छन् ।

साहित्यकार तथा समालोचक अभि सुवेदीले हेमनका कवितामा सरलता र उक्ति सामर्थ्यको अनौठो संयोग भएको लेखेका छन्। हेमनको कवितासड्ग्रह पहाड मसितै यात्रा गर्छको तेस्रो संस्करणमा समालोचक सुवेदीको सङ्क्षिप्त टिप्पणी प्रकाशित छ। सो टिप्पणीमा उनले हेमनका कविताले आफूलाई तान्दै लगेको उल्लेख गरेका छन् 
। उनले लेखेका छन्, "ती आफ्ना, समाजका संस्कति र विलुप्त तर सामाजिक र निजी स्मृतिका अन्तरमा बसेका मौन इतिहासलाई कवितामा मुखरित गई्छन्" (सुवेदी)।

अर्का कवि अविनाश श्रेष्ठको समालोचनात्मक टिप्पणी पनि यसै सड्ग्रहमा समेटिएको छ। उनले हेमन यात्री विम्बमा, प्रतीकमा, सादृश्यमा, उपमाउपमेयमा, चिद्वैषम्यमा र प्रयोगमा अभिव्यक्ति दिने कवि भएको उल्लेख गरेका छन् । उनको विचारमा हेमन नवीन भाषा र शैलीमा आफ़भित्रको कवितालाई चोखो, सड्लो अनि निख्खर अभिव्यक्ति दिने कित्ताका कवि हुन् । उनले लेखेका छन्, "उनी आफ्ना समकालीनहरूको भीडमा छुट्टै किन पनि चिनिन्छन् भने उनी सचेतरूपमा आफ्नो बाटो आफैं बनाउने ऊर्जा, दृष्टि र प्रतिभाले सम्पन्न कवि हुन्" (श्रेष्ठ)।

यस्तै, कवि दिनेश अधिकारीले पनि उनका कवितामा प्रयुक्त शिल्प-सौन्दर्यबारे चर्चा गरेका छन् । उनको दृष्टिकोण पनि सोही सड्ग्रहमा प्रकाशित छ। उनका कवितामा विद्रोह र असन्तुष्टिका भाव प्रस्तुत भए पनि आगोका भिल्का कतै नदेखिने, बरु फिलिड्गाहरूको ताप र रापको अनुभूति हुने अधिकारीले उल्लेख गरेका छन्। "तिक्तता अनुभव नहुने गरी जीवनको विसड्गतिले कता-कता छोएको भान हुन्छ। आहत भएको मनलाई प्रेमको स्निग्धता लेपेर राहत लिएको आभास हुन्छ”" (अधिकारी)।

कवि हेमनका कविताबारे समालोचक महेश पौड्यालले पनि चर्चा गरेका छन् । उनको सड्क्षिप्त ट्पिप्पणी पानि सोही सड्ग्रहमा समावेश छ। यदि कविता माटोको विश्वासका लागि जिम्मेवार छ भने यो समय सम्भवतः हेमन उत्कृष्ट छनोटमध्ये एक हुन सक्ने पौड्यालको धारणा छ।

यसरी विभिन्न अध्येता र समालोचकहरूले कवि हेमनका कविताहरूबारे विभिन्न कोणबाट चर्चा गरेका छन् । अधिकांशले प्रभावपरक विधिबाट सड्ग्रहको समीक्षा गरेका छन् । उनको कविता आमाको गीत : २ को विश्लेषण भने कसैले गरेको देखिंदैन । यो कवितामा प्रयुक्त विम्बमै केन्द्रित भएर कसैले अध्ययन गरेको देखिंदैन । त्यसैले यहाँ पहाड मसितै यात्रा गई्छमा सड्कलित कविता आमाको गीत : २ को बिम्बपरक अध्ययन गरिएको छ।

\section{शोधविधि}

\section{सामग्री सङ्कलन विधि}

उल्लिखित उद्देश्यहरूको प्राप्तिका लागि यस अध्ययनमा प्राथमिक र द्वितीयक दुवै स्रोतहरूबाट सामग्री सड्कलन गरिएको छ। प्राथमिक स्रोतका रूपमा कवि हेमनको कवितासड्ग्रह पहाड मसितै यात्रा गर्छमा सङ्कलित आमाको गीत : २ कवितालाई लिइएको छ। द्वितीयक सामग्रीका रूपमा सम्बन्धित विषयमा लेखिएका विभिन्न ग्रन्थ, अनुसन्धानमूलक लेखहरूको सड्कलन, लेख, अनुसन्धान प्रतिवेदन आदिलाई लिएएको छ।

\section{सामग्री विश्लेषण विधि}

यसरी विभिन्न स्रोतबाट सामग्री सङ्कलन गरी व्याख्यात्मक, वर्णनात्मक र विश्लेषणात्मक विधिको प्रयोगबाट निष्कर्षमा पुगिएको छ। यस अध्ययनमा यी विभिन्न स्रोतबाट सङ्कलित सामग्रीलाई पुस्तकालयीय विधिमार्फत् व्याख्या र विश्लेषण गरिएको छ।

\section{सैद्धान्तिक आधार}

बिम्बको प्रयोगले भाषालाई प्रभावकारी र सुन्दर बनाउँछ। आफ्नो धारणा वा विचारलाई प्रभावकारी रूपमा सम्प्रेषण गर्नकै लागि कविहरूले कवितामा बिम्बको प्रयोग गर्ने गई्छन्। बिम्को प्रयोगले कवितालाई सम्प्रेष्य बनाउने मात्र होइन, सुन्दर पनि बनाउँछ। कविताको भाषा विशिष्ट हुन्छ। यो बोलचालको भाषाजस्तो रुखो वा 
सपाट हुँदैन । यसको आफ्नै भाषा हुन्छ। ललितरागात्मक हुनु कविताको भाषाको वैशिष्ट्य हो । कविताको भाषालाई विशिष्ट र सुन्दर बनाउने थुप्रै उपकरणहरूमध्ये बिम्ब पनि एक महत्त्वपूर्ण उपकरण हो। त्यसैले साहित्यमा वा कवितामा बिम्बको बेग्लै महत्त्व छ। बिम्बविनाको कविताले पाठकमा अपेक्षित प्रभाव पार्न सक्दैन।

\section{बिम्बको व्युत्पत्ति र अर्थ}

सोको अर्थमा बिम्ब भनेको छाया हो । बिम्बको शाब्दिक अर्थ प्रतिच्छाया, प्रतिच्छवि, दर्पण, प्रतिबिम्ब आदि हुन्छन् तर साहित्यमा यसको बेग्लै अर्थ हुन्छ। साहित्यमा भने यसलाई 'काव्यबिम्ब' का रूपमा प्रयोग गरिन्छ। अड्ग्रेजीमा बिम्बलाई Image र काव्यबिम्बलाई Poetic Image भनिन्छ। अड्ग्रेजीमा यसलाई Imagery मात्रै पनि भन्ने गरिएको पाइन्छ। वास्तवमा यो चित्रात्मक भाषा हो। आफ्नो मानसपटलमा भएको चित्रलाई भाषाका माध्यमबाट प्रस्तुत गर्न कविले प्रयोग गर्ने शब्द वा शब्दसमूह नै बिम्ब हो। 'भाषाका माध्यमबाट पाठकका मनमा कुनै दृश्य वा अनुभूतिको प्रभाव अङ्कन गर्नु नै बिम्बको उद्देश्य हो' (विद्रोही, २०७४, प्.१५९)।

नेपाली बृहत् शब्दकोशमा बिम्बको अर्थ यस्तो लेखिएको छ, '१. ऐना, पानी आदिमा देखिने छायाको रूप, छाया मण्डल, प्रतिविम्ब, विम्ब ।... ३. प्रतिमूर्ति, प्रतिमा । ४. कुनै कुराको आभास वा कलक (पोखरेल, २०७२, पृ.9१५९) ।'

साहित्यमा भने बिम्बको अर्थ यतिमा सीमित हुँदैन । साहित्य, अभक कवितामा यसले फरक अर्थबोध गराउँछ। आधुनिक कवितामा भाषिक सौन्दर्य सिर्जनाका लागि यसको विशेष महत्त्व छ। विम्बबारे विभिन्न विद्वान्ले आ-आफ्नै परिभाषा दिएका छन्। 'विम्ब भन्नाले मस्तिष्कमा पर्ने कुनै पनि वस्तुको छाया हो' (बराल र एटम, २०६६, पृ. ४१)। साहित्यमा यस्तो छाया भाषाका माध्यमबाट बसाइन्छ। त्यसैले विम्ब भनेको चित्रात्मक भाषा हो। शर्मा र लुइटेल (२०७२) ले पनि विम्बबारे आफ्नो धारणा प्रस्तुत गरेका छन् । विम्बले साहित्यका कुनै अंशको आलड्कारिक भाषा तथा इन्द्रिय र अनुभूतिलाई आकर्षित तुल्याउने वस्तु र गुणका सङ्केतक सम्पूर्ण शब्दहरूलाई जनाउँछ) (शर्मा र लुइटेल, २०७२, पृ.३२७)।

साहित्यमा बिम्बको अवधारणा मूलतः पश्चिमको देन हो । पूर्वीय आचार्यहरूले यसबारे कुनै छलफल र विमर्श गरेको पाइंदैन । अथवा भनौं, पूर्वीय काव्यशास्त्रमा यस शब्दको प्रयोगसम्म पनि भएको पाइँदैन । समालोचक केशवप्रसाद उपाध्याय (२०६७) ले भने यस शब्दको चर्चासम्म गरेका छन्। उनले काव्य वा कवितामा कल्पनाप्रसूत वा बुद्धिप्रेरित मनोमूर्ति नै बिम्ब भएको आशय व्यक्त गरेका छन् पृ.१९०)। पूर्वीय साहित्यमा प्रचलित अलड्कार नै शब्दान्तर भएर बिम्ब भएको उनको भनाइ छ। उनले यति भनेका छन्, 'आजका बिम्ब नै हिजोका अलङ्कार हुन् (उपाध्याय, २०६७, पृ.१९०) ।'

अड्ग्रेजी साहित्यबाट भारतीय साहित्य हुँदै यो शब्द नेपाली साहित्यमा भित्रिएको पाइन्छ। अड्ग्रेजी साहित्यमा विम्ब (इमेज) को चर्चा एडिसन कालमै भए पनि यसलाई शास्त्रीय रूप दिने पहिलो प्रयास बीसौं शताब्दीको प्रारम्भिक दशकमा भएको हो (सिंह, ?, पृ.९)। अड्ग्रेजी साहित्यको रोमान्टिक-युग (स्वच्छन्दतावादी युग) पछि, अड्ग्रेजी कविताको इतिहासमा लामो समयसम्म देखिएको एक प्रकारको 'काव्यात्मक यथास्थिति' विरुद्धको प्रतिक्रियाले नै विम्बवादको रूपमा साहित्यिक आन्दोलनको रूप लिएको सिंहको भनाइ छ। सन् १९०द मा प्रारम्भ भएको यो नयाँ आन्दोलनका नेता टी. ई. हुल्मे र एफ. एस. फ्लिन्ट थिए। सन् १९१३ मा फ्लिन्टले 'विम्बवाद' शीर्षकमा लेखेको आलोचनात्मक टिप्पणीका प्रमुख स्थापनालाई सिंहले निम्न बुँदाहरूमा उल्लेख गरेका छन् : 
(क) काव्यमा वस्तुको प्रत्यक्षग्रहण ।

(ख) कवव्यलाई अर्थयुक्त बनाउन योगदान नदिने शब्दहरूको सर्वथा त्याग ।

(ग) लययोजनामा यात्त्रिक पद्धतिको त्याग र सड्गीतिक नियमहरूको पालन ।

$$
\text { (सिंह, ?, पृ. १९) }
$$

कवितामा विम्बलाई प्राथमिकता दिने साहित्यिक आन्दोलनलाई 'विम्बवाद' भनिन्छ। यो आन्दोलन पश्चिममा २० औं शताब्दीको प्रारम्भतिर देखा परेको हो। 'विम्बवाद' ९क्षबनष्क० शब्दको प्रयोग पहिलोपल्ट कवि एज्रा पाउन्डले गरेका हुन्। आफ्नो सम्पादनमा सन् १९१२ मा प्रकाशित ग्रन्थ 'द रिपोर्ट्स्' को भूमिकामा उनले यो नयाँ शब्दको प्रयोग पहिलोपल्ट गरे (शर्मा र लुइटेल, २०७२, पृ.३२६)।

अब्राम्स र हार्फम (सन् २०१६, पृ.१७३) ले भने ‘विम्बवाद' लाई लगभग सन् १९१२ र १९१७ को बीचमा इड्ल्यान्डमा मौलाएको र अमेरिकामा अभ बढी तीव्रतासाथ फैलिएको काव्य-परम्पराका रूपमा उल्लेख गरेका छन् । कवितामा स्वच्छन्दतावादी भावुकतापूर्ण शैलीविरुद्ध टी.ई. हुल्मेले अगाडि सारेको काव्यिक सिद्धान्तको आंशिक प्रभावमा यो अभियान थालिएको थियो। कवि एवम् चिन्तक एज्रा पाउन्ड यस अभियानका पहिलो नेता थिए। लन्डनमा बस्ने अड्ग्रेज र अमेरिकी लेखकहरूको एउटा समूहले यस अभियानको थालनी गय्यो (अब्राम्स र हार्फम, सन् २०१६, पृ.१७३)। यो अभियानमा हुल्मेको सौन्दर्यवादी दर्शन तथा काव्य सिद्धान्तको प्रभाव परेको मानिन्छ। “हुल्मेको ‘विम्ब नै कविकर्मको चरम उपलब्धि हो' भन्ने अभिव्यक्तिलाई विस्बवादको पहिलो घोषणाका रूपमा लिइन्छ" (शर्मा र लुइटेल, २०७२, पृ.३२६)।

उपर्युक्त छलफलबाट के बुकिन्छ भने साहित्यको अध्ययन गर्दा पाठकको मस्तिष्कमा निर्माण हुने 'मानसिक चित्र' वा 'दृश्य' नै विम्ब हो। अब्राम्स र हार्फम (सन् २०१६, पृ.१७२) ले यसलाई समालोचनामा अधिक साका र अर्थवत्ताका आधारमा सबैभन्दा चलायमान पदका रूपमा प्रस्तुत गरेका छन्। अब्राम्स र हार्फम (सन् २०१६) ले कवि सी. डे लिविसलाई उद्धृत गर्दे लेखेका छन्, ‘चित्रहरूको बाहुल्यबाट निर्माण भएको कविता आफैं एउटा चित्र हुन सक्छ' (पृ.१७२)। विम्बलाई दृश्यमा मात्र सीमित गर्न भने सकिंदैन। विम्बको सम्बन्ध इन्द्रियसँग हुन्छ। इन्द्रियसंवेद्य भावहरूलाई मूर्त रूपमा प्रस्तुत गर्न विम्बको सहारा लिने गरिन्छ। इन्द्रियसंवेद्यताका आधारमा शब्द तत्त्वसँग सम्बद्ध विम्बलाई श्रव्य विम्ब, दृश्य तत्त्वसँग सम्बद्ध विम्बलाई चाक्षुष विम्ब, जिह्वा (रसना) तत्त्वसँग सम्बद्ध विम्बलाई रसविम्ब वा आस्वाद्य विम्ब, घ्राण तत्त्वसँग सम्बद्ध विम्बलाई घ्राण विम्ब वा घ्रातव्य विम्ब र स्पर्श तत्तवसँग सम्बद्ध विम्बलाई स्पृश्य वा स्पर्श विम्बका रूपमा वर्गीकरण गर्ने गरिएको पाइन्छ (गौतम, २०६०, प्. २१-२२)।

\section{परिणाम तथा छलफल}

पहाड मसितै यात्रा गईई हेमन यात्रीको पहिलो काव्यकृति हो। उनी हृदयका कवि हुन्। उनले आफ्ना कविताहरूमा जीवनका विविध पक्षलाई विषय बनाएका छन् । जीवनका हर्ष-विस्मात, आशा-निराशा, सुख-दु:ख, प्रेम-विछोड, माया-घृणा, आह्लाद-व्याघातजस्ता विषय उनका कवितामा विषय बनेर आएका छन्। हेमनको यो कविता सड्ग्रहमा सड्कलित कविताहरूले नेपाली जनजीवनका जटिलता र अप्ठ्याराहरूलाई काव्यिक अभिव्यक्ति दिएका छन् । उनका कविताहरूले मानवीय जीवनका कोमल भावहरूलाई सम्प्रेषण गरेका छन्। वर्चश्वशाली समुदायबाट कमजोर समुदायमाथि इतिहासमा भएका अन्याय वा भाषिक-सांस्कृतिक दमन र त्यसले समुदायमा 
पारेका प्रभाव, सांस्कृतिक हस्तक्षेप, गरिब र विपन्न नेपाली जनका कष्टकर एवम् पीडादायी जीवनको मार्मिक चित्र पनि उनका कवितामा पाइन्छ।

११६ पृष्ठमा फैलिएको यस कृतिमा ३६ वटा कविताहरू छन् । विवेच्य कविता 'आमाको गीत : २' यस सड्ग्रहको दोस्रो कविता हो। यो पाँचवटा पड्क्तिपुज्जबाट निर्मित गद्यकविता हो। पहिलो पड्क्तिपुज्जमा पाँचवटा र दोस्रोमा चार पड्क्ति छन् भने तेस्रो पड्क्तिपुज्जमा नौ पड्क्तिको आयोजना गरिएको छ। यस्तै चौथो पड्क्तिपुज्जमा पाँच र पाँचौँमा नौवटा पड़क्तिहरू छन्। कविताको सबैभन्दा सानो पड़क्ति तीनवटा शब्दबाट निर्मित छ, भने सबैभन्दा लामो पड्किक्ति सातवटा पड्कि छन् । सरल र हृदयसंवेद्य विम्बहरूको प्रयोग तथा काव्यिक भाषाका कारण कवितामा आन्तरिक सड्गतित सबल बनेको छ।

यसमा युद्धमा बेपत्ता छोराको सम्कनामा व्यथित आमाको पीडादायी अवस्थालाई मार्मिक ढड्गले काव्यिक अभिव्यक्ति दिएएको छ। प्रस्तुत कवितामा विविध विम्बहरूको आकर्षक संयोजनबाट भावलाई हार्दिक र प्रभावकारी बनाइएको छ। यी विम्बहरूले नेपालको ग्राम्य र प्राकृतिक परिवेश, छोरा गुमाएकी आमाको मनोदशा तथा युद्धले दिने पीडादायी परिणामलाई जीवन्त बनाएका कारण विवेच्य रचनाका रूपमा यसलाई छनोट गरिएको हो । विम्ब प्रयोगका दृष्टिले पनि यो कविता उल्लेख्य छ। यहाँ तिनै विम्बहरूको विश्लेषण गरिएको छ।

\section{आमाको गीत-२ को बिम्बपरक अध्ययन \\ नादविम्ब}

यो संवेदनात्मक विम्बअन्तर्गत पछ। ध्वनिसँग सम्बन्धित विम्बहरूलाई नादविम्ब भनिन्छ। कर्णसंवेद्य ऐन्द्रियिक विम्बहरूलाई नादविम्ब भानिने गौतम (२०६०, पृ.१५२) ले लेखेका छन्। यस्ता विम्बमा कुनै ध्वनिको अनुकरणलाई प्रयोग गरिन्छ। विवेच्य कवितामा पनि कवि यात्रीले यस्तो विम्बको प्रयोग गरेका छन्।

हिउँदे बतासको लैबरीमा

थपडी बजाइरहेछन चिउरीका पातहरू

$$
\text { (यात्री, २०७१, पृ. २९) }
$$

प्रस्तुत कवितांशमा बतासको लैबरी, चिउरीका पातहरूले थपडी बजाउनु जस्ता विषयले नादविम्बको सिर्जना गरेका छन्। यी भावविम्बहरूले ग्रामीण प्राकृतिक वातावरणलाई सङ्केत गरेका छन्। हिउँद याममा बतासको स्पर्शबाट आपसमा ठोक्किएर चिउरीका पातहरूबाट निस्किने आवाजलाई कविले थपडीसँग सादृश्य गरेर यहाँ सुन्दर विम्बको सिर्जना गरिएको छ। यी विम्बहरूले नेपाली ग्राम्य प्राकृतिक परिवेशलाई जीवन्त बनाएका

छन् ।

\section{प्राकृतिक विम्ब}

प्राकृतिक सौन्दर्यको चित्रण गर्ने ऋममा काव्यमा प्राकृतिक विम्बको सिर्जना हुन्छ। कोमल अनुभूतिको निर्माण गर्दै पाठकको हृदयमा प्रभाव पार्न काव्यमा प्रकृति जगत्को विम्बमय चित्रण गरिन्छ। त्यसै क्रममा काव्यमा प्राकृतिक विम्बको सिर्जना हुन्छ। 'मानवनिरपेक्ष सौन्दर्यसत्ताका रूपमा प्रकृतिलाई अवलोकन गरी त्यसैलाई माध्यम बनाएर काव्यमा सौन्दर्य भर्दा प्राकृतिक विम्बको उपस्थिति हुन्छ (गौतम, २०६०, पृ.१३७) ।' कविहरूले यस विम्बको प्रशस्त प्रयोग गई्छन् । असचेत रूपमै भए पनि कविहरूले प्राकृतिक विम्बको प्रयोग प्राचीन कालदेखि नै गर्ने गरेको पाइन्छ, 
। आमाको गीत-२ मा पनि कवि हेमनले प्राकृतिक विम्बको सफल प्रयोग गरेका छन् । कवितामा गरिएको प्रकृतिको विम्बमय प्रस्तुतिले पाठक-मनलाई प्रकृतिको निकट पुच्याउँछ। हेरौं एउटा अंश :

भर्लेनि पाखामा कोरस अलापिरहेछन्

एक हुल हलेसोका बथान

(यात्री, २०७१, प्. २९)

प्रस्तुत कवितांशमा प्रयोग भएका हलेसोको बथानले कोरस अलापेको विम्बले प्रकृतिको चित्रलाई सुन्दर ढड्गले प्रस्तुत गरेको छ। हलेसोको बथानले निकाल्ने आवाजलाई कोरस (गायनको ऋममा प्रयोग गरिने सामूहिक आवाज) सँग सादृश्य गरेर कविले प्राकृतिक विम्बको आयोजना गरेका छन् । प्रस्तुत विम्बले पाठकहरूलाई नेपाली प्रकृतिको नजिक पुच्याउँछ। प्राकृतिक विम्बकै प्रयोग गरिएका अन्य कवितांश :

र खोलाको चेप्टे ढ़ड़्गामा बसेर

छारोले लेख्न सिकाएको आफ्नै नाम

लेख्तै-मेट्तै गर्छिन्।

(यात्री, २०७१, पृ. ३०)

साँभपख घरमुन्तिरको बूढो खरबारीमा

हँसिया बोकेर हिँडेकी आमा

(यात्री, २०७१, पृ. ३०)

उपर्युक्त कवितांशहरूमा पनि प्राकृतिक विम्बहरूको प्रयोग प्रभावकारी ढड्गले गरिएको छ। अगिल्लो कवितांशमा प्रयुक्त खोलाको चेप्टे ढुड्गा र पछिल्लो कवितांशमा प्रयुक्त बूढो खरबारीले प्राकृतिक चित्रलाई प्रस्तुत गरेका छन् । यी विम्बहरूले पाठकलाई नेपाली ग्रामीण प्रकृतिको सुरम्य काखमा पुच्याउँछ् । प्राकृतिक विम्बको वैशिष्ट्य नै यही हो ।

\section{छायात्मक विम्ब}

छायात्मक विम्बले छायात्मक र अस्पष्ट भावको आभास गराउँछ। यस्तो विम्बले मधुरो चित्र देखाउँछ। 'अस्पष्ट छायात्मक, धूमिल आकृतिपरक र विम्बप्रतिविम्ब भाव देखिनु छायात्मक विम्बको सामान्य अभिलक्षण हो (गौतम, २०६०, पृ.११५) ।' यस्ता विम्बहरूले मस्तिष्कमा धूमिल चित्र सिर्जना गराएर अनौठो काव्यानुभूति गराउँछन्। हेमनको प्रस्तुत कविताले पनि छायात्मक विम्बको सुन्दर प्रयोगमार्फत् हार्दिक काव्यानन्द प्रदान गई।

नजिकै बगिरहेको छ चिपचिपे खोला

आमा रुखवाट ओर्लेर कुवा बनाउँछिन्

र कुवाको ऐनामा

युद्धमा बेपत्ता छोराको अनुहार देख्छिन ।

(यात्री, २०७१, पृ. २९)

प्रस्तुत कवितांशमा 'कुवाको ऐनामा युद्धमा बेपत्ता छोराको अनुहार देखेको' प्रसड्ग छायात्मक विम्बको राम्रो उदाहरण हो। प्रस्तुत विम्बको माध्यमबाट कविले आमाको हृदयमा भएको छोराको सम्कनालाई सम्मूर्तित बनाएका छन्। यस विम्बले युद्धमा बेपत्ता छोराको सम्कनामा व्यथित आमाको पीडादायी मानसिक अवस्थालाई 
सुन्दर ढड़गले अभिव्यक्त गरेको छ। आमाको सम्भनाभरि र मनभरि छोराको चित्र व्याप्त भएको हुँदा आमाले जहाँ हेर्दा पनि छोराकै अनुहार देखेको भाव यहाँ जीवन्त बनेर प्रस्तुत भएको छ। यो भावलाई सफलतापूर्वक सम्प्रेषण गर्न छायात्मक विम्बले महत्त्वपूर्ण भूमिका निर्वाह गरेको छ। यो विम्बले कवितालाई सम्प्रेष्यमात्र बनाएको छैन, कोमल र हार्दिक पनि बनाएको छ। भावको विम्बीकरण यसकै लागि गरिन्छ।

\section{सरल विम्ब}

कवितामा यस्ता विम्बहरूको प्रयोग अधिक हुन्छ। यस्ता विम्बहरू जटिल हुँदैनन् र कविताको भावलाई सजिलै बोध गर्न सघाउँछन् । सरल विम्ब संशिलष्ट नभई स्वतन्त्र हुन्छ। 'मुक्त र स्वतन्त्र रूपमा प्रयुक्त विम्ब नै सरल विम्ब हुन् (गौतम, २०६०, पृ.२२२)।' यस्तो विम्ब कविताभरि एउटै अर्थमा प्रयुक्त हुन्छ। कवि हेमनले पनि आफ्ना कवितामा यस्ता सरल विम्बहरूको प्रशस्त प्रयोग गरेका छन्। सरल विम्बहरू प्रयुक्त कविताको भाव बोधगम्य हुन्छ। हेरीं एउटा कवितांश :

आमा पारिपट्टि पश्चिम फर्किएको

कटुसको भुयाङमा घडी हेर्छिन

पात-पातमा पहेंलो घाम कुण्डिएको देखेर, (यात्री, २०७१, पृ.३०)

प्रस्तुत कवितांशमा 'कटुसको क्याङमा घडी हेन्नु' सरल विम्बको नमुना हो। ग्रामवासीहरूले रुखको छाया हेरेर वा रुखका पातहरूको बीचबाट देखिने घामको अवस्थितिबाट समयको बोध गर्ने सन्दर्भ यहाँ स्पष्ट भएको छ। प्रस्तुत विम्बले भावलाई बोधगम्य बनाएको छ। यो विम्ब जटिल नभएको हुँदा यसको प्रयोगबाट कविताको भाव सहजै बोध गर्न सकिन्छ। जटिल विम्बको प्रयोगले कवितालाई क्लिष्ट र दुर्बोध्य बनाउँछ तर सरल विम्बले कवितालाई बोधगम्य र सहजसंवेद्य बनाउँछ। माथिको कवितांशमा पनि सरल विम्बको प्रयोगले कविता सरल र संवेद्य बनेको छ।

\section{निजी विम्ब}

कविद्वारा सिर्जित नयाँ विम्ब नै निजी विम्ब हो। यस्ता विम्बहरू परम्पराबाट रुढ भएका हुँदैनन् । यस्ता विम्बहरूमा कविको कल्पना शक्ति र सामर्थ्य भल्किन्छ। विम्बवादी कवि एज्रा पाउन्डले भनेका छन् - 'जीवनभर लगाएर थुप्रै मोटा ग्रन्थहरूको रचना गर्नुभन्दा एउटा विम्बको सिर्जना गर्नु उत्तम हुन्छ (उद्धृत, गौतम, २०६०, प्.७)।' कवि पाउन्डको यस भनाइबाट पनि कवितामा निजी विम्बको महत्त्व प्रस्ट हुन्छ। त्यसैले सक्षम कविहरू जहिले पनि निजी विम्बको सिर्जना गर्ने प्रयासमा हुन्छन् । कवि हेमनले पनि आफ्ना कविताहरूमा निजी विम्बको प्रयोग गर्ने गरेका छन् । प्रस्तुत कवितामा पनि उनले निजी विम्बको प्रयोगबाट सुन्दर भाव अभिव्यक्त गरेका छन् । हेरी एउटा नमुना :

डँडाल्नोभरि हरियो गीतको भारी बोकेर घर फिर्छिन्, (यात्री, २०७१, पृ.३०)।

प्रस्तुत कवितांशमा प्रयुक्त ‘डँडाल्नोभरि हरियो गीतको भारी बोक्नु' निजी विम्बको उदाहरण हो। यहाँ 'हरियो गीत' ले हरियो घाँसलाई बुकाएको छ। उपर्युक्त विम्बले डँडाल्नोमा हरियो घाँसको भारी बोकेर हिँडिरहेको ग्रामवासी महिलाको विम्बीय चित्र अगाडि आउँछ। यस विम्बको प्रयुक्तिले यहाँ ग्रामीण जीवनको कल्को आउँछ। निजी विम्बको प्रयोग यहाँ प्रभावकारी रूपमा भएको छ। 


\section{निष्कर्ष}

यसरी के देखिन्छ भने यात्रीको 'आमाको गीत : २' मा विम्बहरूको सुन्दर संयोजन गरिएको छ। प्रस्तुत कवितामा विविध विम्बहरूको सुन्दर संयोजनबाट युद्धमा बेपत्ता छोराको सम्कनाले पीडित आमाको वेदनालाई चित्रण गरिएको छ। कवितामा विम्बहरूका माध्यमबाट ग्रामीण परिवेश र ग्रामवासीका गतिविधिलाई पनि सुन्दर ढड्गले अभिव्यक्त गरिएको छ। कवि यात्री विम्बहरूको सुन्दर संयोजनबाट भावपूर्ण कविता सिर्जना गर्न सिपालु छन् । कवि यात्रीले बिम्बात्मक अभिव्यक्तिमार्फत् कवितालाई सुन्दर र काव्यिक बनाएका छन्। प्रस्तुत कवितामा भाव अभिव्यक्तिका लागि विम्बहरूको उत्कृष्ट संयोजन गरिएको छ। विम्बबहुल कविताहरूको सिर्जना गर्नु कवि हेमनको विशेषता हो । उनको यो विशेषता समीक्ष्य कविता 'आमाको गीत : २' मा पनि प्रकट भएको छ। विम्बहरूकै सुन्दर र आकर्षक संयोजनले समीक्ष्य कविता हृदयसंवेद्य बनेको छ। प्रस्तुत कवितामा प्रयोग गरिएका विम्बहरू नेपाली ग्राम्य समाज र प्रकृतिबाटै टिपिएका हुँदा सरल, स्वाभाविक र संवेद्य छन् । यी विम्बहरूले कविताको सम्प्रेषणमा वाधा खडा गर्नुको साटो सहजता सिर्जना गरेको निष्कर्ष माथिको छलफलबाट निस्कन्छ। सुन्दर विम्बहरूको उचित आयोजनाले कवितालाई सुमधुर र भावयुक्त बनाएको छ।

सरल र आकर्षक विम्ब प्रयुक्तिका कारण विश्लेष्य कविता युद्धमा छोरा गुमाएकी पचपन्न वर्षीया आमाको मनोदशालाई प्रभावकारी र मार्मिक रूपमा प्रस्तुत गर्न सफल भएको छ। बेपत्ता छोराको वियोगमा भ्रान्त मनोदशामा पुगेकी आमा जताततै आफ्नै छोराको चित्र देख्छिन् । यही भावलाई कुशलतापूर्वक सम्प्रेषण गर्न यहाँ आयोजित विम्बहरू सफल छन्। विश्लेष्य कवितामा प्रयुक्त विम्बहरू नेपाली समाजकै विभिन्न क्षेत्र र नेपाली प्रकृतिबाट टिपिएका छन् । त्यस कारण कविताको अर्थ सम्प्रेषण प्रभावकारी बनेको छ। विम्बहरूकै सफल आयोजनाका कारण कविता सम्प्रेष्य र सहज संवेद्य बनेको यस अध्ययनको निष्कर्ष छ।

\section{सन्दर्भसामग्री}

अब्राम, एम. एच. र जिओफ्रे गल्ट हार्फम (सन् २०१६), अ ग्लोसरी अफ लिटररी टर्म्स (एघारौं सं.), सिनेज लर्निङ इन्डिया प्रा.लि. ।

उपाध्याय, केशवप्रसाद (२०६७), पूर्वीय साहित्यसिद्धान्त (पाँ. सं.), साभा प्रकाशन ।

गिरी, अमर (२०७३ क), समकालीन नेपाली कविताको वैचारिक परिप्रेक्य, साभा प्रकाशन ।

गिरी, अमर (२०७३ ख) (सम्पा.), काव्यविमर्श, नेपाल प्रज्ञा-प्रतिष्ठान ।

गौतम, लक्ष्मणप्रसाद (२०६०), समकालीन नेपाली कविताको विम्बपरक विश्लेषण, साभा प्रकाशन ।

बराल, कृष्णहरि र नेत्र एटम (२०६६), उपन्यास सिद्धान्त र नेपाली उपन्यास (ते.सं.), साभा प्रकाशन ।

यात्री, हेमन (२०७१), पहाड मसितै यात्रा गई्छ (ते.सं.), फिनिक्स बुक्स ।

लुइटेल, खगेन्द्रप्रसाद (२०६०), कविता सिद्धान्त र नेपाली कविताको इतिहास, नेपाल राजकीय प्रज्ञा प्रतिष्ठान ।

विद्रोही, राजेश (२०७४), "समकालीन नेपाली कवितामा जनजातीय सांस्कृतिक विम्ब", दृष्टिकोण (६), महेन्द्र बहुमुखी क्याम्पस, त्रिभुवन विश्वविद्यालय।

सिंह, केदारनाथ (?), आधुनिक हिन्दी कविता मे विम्बविधान, भारतीय ज्ञानपीठ प्रकाशन ।

सुवेदी, राजेन्द्र (२०६४), नेपाली उपन्यास : परम्परा र प्रवृत्ति (दो.सं.), साका प्रकाशन ।

शर्मा, मोहनराज र खगेन्द्रप्रसाद लुइटेल (२०७२), पूर्वीय र पाश्चात्य साहित्यसिद्धान्त (चौ.सं.), विद्यार्थी पुस्तक भण्डार । 